\title{
Reginald Scot and King James VI: The Influence of Skepticism
}

\author{
Kimberly Bercovice
}

The witch-hunts in England were not as robust as in Scotland or in continental Europe, which was the result of the failure to fully embrace diabolism. An air of skepticism appeared to revolve around the notion of diabolism being the root of maleficent magic and may have kept diabolism from embedding itself in the beliefs and traditions of the common English people. One writer in particular, Reginald Scot was vehemently opposed to the idea that witchcraft resulted from the spiritual realm. Scot was the first of the English skeptics. He sought to debunk witchcraft by undertaking a systematic approach in combination with his deep Calvinistic convictions. His book, The Discoverie of Witchcraft was printed in 1584 in an effort to demonstrate that witchcraft was nothing more than illusions and trickery and was not the result of a demonic pact with Satan.

Were the efforts of Scot, along with other skeptics, responsible for preventing diabolism from becoming the driving force behind English witch-hunts and thus limiting their magnitude in comparison to those in continental Europe? I would argue that Scot's rational, common sense, and theologically well-grounded approach was able to appeal to those whose own common sense and traditional beliefs prevailed in the end, including King James VI. While Scotland's King, James VI held a firm belief in the reality of witches and witchcraft and published Daemonologie in 1597 as a tool to educate his subjects about the perils of maleficent magic and to admonish the doubters. As I will explain below, Scot was one of James' particular targets. Upon becoming the King of England in 1603, James VI (now James I of England as well) reprinted his book (1604) to also educate his English subjects on the threat of witches. However, the King appeared to change his own strongly opinionated beliefs about witchcraft a few years later when he began to actively expose those who made false claims.

Reginald Scot was a country gentleman from Kent who came from a good family. And, although his critics accused him alternatively of being an atheist or a Puritan for his stance on witches and witchcraft, he was a devout Calvinist. It has been suggested in the literature that he attended Hart Hall in Oxford, however, there has been no evidence found to indicate he completed his degree before returning to Kent. Upon returning home Scot married and had a daughter. He took up the running of his estate and engaged in husbandry and gardening and in 1574 he published a book on the topic of horticulture, A Perfect Platforme of a Hoppe-Garden and 
necessary instructions for the making and maintaining thereof; the book produced three editions within five years. ${ }^{1}$ Why Scot turned his attention from horticulture to the discrediting of witchcraft is not entirely clear. What is clear is that the subject was a deeply important one to him. Scot chose to publish his book at his own expense, which demonstrated his profound awareness and understanding of the controversial nature of producing his book in that time. He was well aware his book would not be well received, but he clearly felt a strong need to contribute his thoughts and understanding on the events taking place around him. He even went so far as to protecting the printer from backlash by not revealing their name.

Historians have tried to explain Scot's desire to publish a book denouncing witchcraft, motives such as sympathy, justice seeking, and honouring his religious beliefs, are a few of the motives they have suggested. In his study of Scot, Philip Almond believed it was very likely that he attended at least one of the 14 prosecutions that took place Kent between 1565 and 1584, the year Scot's book was published, and it can be reasonably assumed that his sensibilities had been offended. ${ }^{2}$ I would agree with this position based on a letter Scot addressed to his uncle, the right worshipful Sir Thomas Scot Knight:

Sir, I see among other malefactors manie poore women convented before you for working of miracles, other wise called witchcraft...See first whether the evidence be not frivolous, \& whether the proofes brought against them be no incredible, consisting of ghesses, presumptions, \& impossibilities contrarie to reason, scripture and nature. ${ }^{3}$

Almond also cited a letter Scot wrote to Sir Roger Manwood ascribing his work as being on behalf of the poor, aged, and simple as evidence of his offense. ${ }^{4}$ John Teall, focusing on Calvinism, credited Scot's principal motive to a desire to "glorify God by reserving to him alone powers which the witch-monger seems to attribute to a mere creature." 5 Reading Scot's words in his first book and chapter, we can see that both motivated him:

As thought there were no God in Israel that ordereth all things according to his will; punishing both just and unjust with greefs, plagues, and afflictions in

\footnotetext{
${ }^{1}$ Wallace Notestein, A History of Witchcraft in England from 1558 to 1718, (Baltimore: The Lord Baltimore Press, 1911), 85, Project Gutenberg EBook.

2 Philip C. Almond, England's First Demonologist: Reginald Scot and 'The Discoverie of Witchcraft', (London: GBR: I.B. Tauris, 2011), 14, ProQuest ebrary.

${ }^{3}$ Marion Gibson, ed., Witchcraft and Society in England and America 1550-1750, (New York: Cornell University Press, 2003), 78.

${ }^{4}$ Almond, England's First Demonologist, 9 - 14.

5 John L. Teall, "Witchcraft and Calvinism in Elizabethan England: Divine Power and Human Agency." Journal of the History of Ideas 23, no.1 (1962): 31
} 
maner and forme as he thinketh good: but that certeine old women heere on earth, called witches, must needs be the contrivers of all mens calamites, and as though the themselves were innocents, and had deserved no such punishments. ${ }^{6}$

In The Discoverie of Witchcraft, Scot worked to systematically disprove the illusions and trickery of witchcraft, admonish the social and legal communities, and chastise those who took God's power and placed it in Satan's hands. Estes Leland contended that Scot was deeply religious and applied his convictions to help form an understanding of the nature of witchcraft, which resulted in Scot's reasoning that witches and witchcraft was nothing more than an unfortunate delusion. ${ }^{7}$ His approach was one based not only in his religious beliefs, but also on rationality and common sense, and done in an almost scientific - albeit in a rudimentary manner, in an effort to provide clear evidence of the fallacy of witchcraft. Scot even went so far in his experiments as to attempt to be enrolled in the "devil's league" as a means of discovering the truth. ${ }^{8}$ Interestingly Scot did not deny the existence of witches in and of themselves. He determined that witchcraft resulting from interactions with demons could not have been true given his deeply held theological beliefs in the incorporeality of spirit which prohibited interactions between humans and demons. Therefore, because of the prohibition on demonic-human interaction witchcraft, as a result of demonic influence, was not possible. ${ }^{9}$

Scot's writings demonstrated that he possessed a deep knowledge of both the Bible and church fathers. His argument against witchcraft was firmly grounded in the Protestant belief that the age of miracles had past and thus, the crime of witchcraft was not possible:

And I challenge them all (even upon the adventure of my life) to shew one peece of a miracle, such as Christ did trulie, or such as they suppose this witch diabolicallie, but be it not with art nor confederacie, whereby some colour thereof may be made; neither are there any such vision in the daies shewed. Heretofore God did send his visible angels to men: but now we heare not of such apparitions, neither are they necessarie. ${ }^{10}$

\footnotetext{
${ }^{6}$ Reginald Scot. The Discoverie of Witchcraft. (New York: Dover Publications, Inc., 1972), Book I, Chap I, 1

${ }^{7}$ L. Estes Leland, and Reginald Scot, "Reginald Scot and his 'Discoverie of Witchcraft': Religion and Science in the Opposition to the European Witch Craze." Church History 52, no. 4 (1983): 450.

${ }^{8}$ Ibid, 445.

${ }^{9}$ S. F. Davis, "The Reception of Reginald Scot's Discovery of Witchcraft: Witchcraft, Magic, and Radical Religion." Journal of the History of Ideas 74, no. 3 (2013): 383.

${ }^{10}$ Scot, The Discoverie of Witchcraft, book VII chap. XIV, 86
} 
Scot's beliefs and his description of God's power were such that all manifestations of that divine power must be attributed to his direct activity, not his permissiveness, as the demonologists suggested. Teall understood Scot's position in rejecting the witch; "[n]ot only would she [the witch] enslave God; as an irrational force she would impede that orderly course of nature which it is our duty to understand and explain," his rejection fit not only within his belief system, but also with his orderly and rational world. ${ }^{11}$ Scot also did not deny the existence of Satan or devils/demons. Leland found that Scot's issue was not with the believability, but rather with the biblical writers whom he believed used the term metaphorically and he took issue with the Catholic Church's use of it in the literal sense to state a person was possessed when in fact the person was, in Scot's opinion, a lunatic. ${ }^{12}$ Brian Levack pointed out that the Catholic Church used possession by the devil and the accompanying exorcism ceremonies and rituals to demonstrate their power to perform miracles with God's blessing as the one true church. The Puritans, on the other end of the spectrum were also believers in possession, but they used what they deemed to be the "scripturally warranted" methods, such as prayer and fasting, which allowed God to intervene and end the possession quietly. The English Church, however, set out to discredit both groups and reveal fraudulent possessions thus inadvertently supporting Scot's position that a demon interacting with humans through possession or witchcraft was impossible. ${ }^{13}$ Another key difference between the English Protestant beliefs concerning witches and their diabolic pacts and those of continental European Catholics was the Catholic concept of inversion to describe witches' ceremonies and behaviours. The Protestant beliefs on witchcraft did not contain the inversion of their ceremonies or rituals, nor did it include black masses or sabbats. When the rare incidents of communal gatherings of witches did occur the witches were noted eating only ordinary foods, such as beef, and drinking ale. ${ }^{14}$ The vast majority of English trials resulting from charges of maleficent magic were generally contained within small areas. Much in the manner that Scot had referred when he deduced who was being primarily being accused, "...miserable wretches are so odious unto all their neighbours..." and a charge of witchcraft became the means to having these unwanted people removed from their community. ${ }^{15}$ English theologians and judges did not place the same emphasis on diabolism and thus the fear that accompanied diabolism had not driven the citizens of England to engage in the same

\footnotetext{
11 Teall, "Witchcraft and Calvinism," 33.

${ }^{12}$ Leland, "Reginald Scot," 450.

${ }^{13}$ Brian P. Levack, "Possession, Witchcraft, and the Law in Jacobean England," Washington and Lee Law Review 52, no. 5 (1995): 1627, http://scholarlycommons.law.wlu.edu/wlulr/vol52/iss5/3

${ }^{14}$ Christina Larner, "Witches Beliefs \& Witch-hunting in England \& Scotland." History Today 31, no. 2 (1981): 36, EBSCOhost.

${ }^{15}$ Scot, Discoverie, book I, chap III, 4.
} 
level of witch-hunting as was seen in continental Europe; the common people appeared to remain focused on ridding themselves of nuisance neighbours.

King James I was the most influential critic of Scot and his book The Discoverie of Witchcraft. James had been convinced of the power of witches and witchcraft while he was still James VI king of Scotland between the years 1590 to 1597 during which time he took an avid interest in the trials of the North Berwick Witches. The witches had been accused of raising storm in an attempt to kill James and his new wife on their return voyage to Scotland from Denmark. The results of the trials had infuriated the King after the accused witches named an aristocrat, the earl of Bothwell whom they accused of wanting James and his bride dead. Bothwell had been able to defend his honour and the King had been unable to assemble an assize of Bothwell's peers, which resulted in his ability to avoid facing trial. ${ }^{16}$ Christine Larner credited James, and his anger over the use of witchcraft by to the North Berwick Witches to threaten his life, with introducing the concept of the demonic pact to the Scottish people. ${ }^{17}$ Larner believed these events turned Scotland into a witch-hunting state, but this did not appear to follow James into England. As James Sharpe observed, there appeared to be a change in the King's attitudes. His reputation as Scotland's James VI - "legendary witch-hunter," had appeared to shift to the more reasonable and moderate King James I of England. And while James did support the death penalty for all those convicted of witchcraft, regardless of age, gender or social standing, he was just as likely to intervene if the evidence was found lacking, as he was to secure a conviction as his reign wore on. ${ }^{18}$

James first published his book, Daemonologie in Edinburgh in 1597. His book served to be as much a discourse on the topic of witchcraft and pacts with the devil as it did to educate his subjects of the dangers and evils of witchcraft and witches. The book was also used as a means to define the lawfulness of certain forms of natural and maleficent magic. James also used the book to set about rebuking any doubters, naming Scot specifically, indicating that Scot's writings must have held a level of credibility in the King's mind that he felt required to condemn in order to maintain the validity of his own assertions:

The fearefull abounding at his time in this countrie, of these detestable slaues of the Deuill, the Witches or enchaunters, hath moved me (beloued reader) to dispatch in post, this following treatise of mine, not in any wise (as I protest) to serue for a shew of my learning \& ingine, but onely (mooued of conscience) to preasse thereby, so farre as I can, to resolue the doubting harts of many; both that such assaultes of Sathan are most certainly practized, \& that

\footnotetext{
${ }^{16}$ Deborah Willis, Malevolent Nurture: Witch-Hunting and Maternal Power in Early Modern England, (London: Cornell University Press, 1995), 128.

${ }^{17}$ Christina Larner, Witchcraft and Religion: The Politics of Popular Belief, ed. Alan Macfarlane, (New York: Basil Blackwell, 1984), 10.

18 James Sharpe, Instruments of Darkness: Witchcraft in Early Modern England, (Philadelphia: University of Pennsylvania Press, 1996), 48-49.
} 
the instrumentes thereof, merits most severly to be punished: against the damnable opinions of two principally in our age, wherof the one called SCOT an Englishman, is not ashamed in publike print to deny, that ther can be such a thing as Witch-craft: and so mainteines the old error of the Sadducees, in denying of spirits. ${ }^{19}$

During James' first year as the King of England Parliament approved a new witchcraft statute extending the scope of the crime to include maleficent magic along with demonological elements. The new statutes also created harsher penalties for those convicted under the new guidelines. However, Notestein found that the while the new statute simplified the ability to charge a woman with witchcraft on the accusations of her neighbours, it did not send her to her death unless a death had occurred in the vicinity and could be related to her. ${ }^{20}$ Therefore, maleficent charges of magic dominated the trials that occurred following the changes in the statute. The resulting nature and effect of this law lent credibility to Scot's earlier argument about using witchcraft to rid undesirables from their communities as opposed to fearing diabolical witchcraft.

There were no laws or statutes that made possession by a demon a crime, only a witch suspected of causing a possession could be charged. The lack of criminality was because it was not considered to be a voluntary condition although it did allow people to attribute socially unacceptable behaviours such as acting out publicly, not following social norms, or engaging in extramarital affairs to the devil - behaviours that as Scot noted would otherwise be considered lunacy. Levack pointed out that possession, and by extension its permissibility, permitted a person to behave in what would have otherwise been seen as an illicit manner. A claim of possession allowed for impulses to be acted upon without fear of condemnation by the community. ${ }^{21}$ Almost eight years after he publicly reprimanded Scot for his witchcraft denials, in August of 1605, the case of Anne Gunter came to James' attention. Anne Gunter was a woman who had professed to be possessed; however, doubt surrounded her claims resulted in King James visiting her himself. After examination by the King's physicians and having had four interviews with the King himself, Anne was found to have been a fraud, a "little counterfeit wench" as James referred to her in a letter to his son. ${ }^{22}$ Despite his original stance on witches and witchcraft, James had begun to delight in exposing the hoaxes, much in the same manner as Scot himself had done in his book. I believe it is evident that despite Scot's book having been ridiculed and suppressed by the James, it had made a bigger impression on the King than it has been given credit for. Given his initial publicly negative response to Scot,

${ }^{19}$ James I, King of England, 1566-1625, Daemonologie, (1597), Preface to the Reader, Internet Archive.

${ }^{20}$ Notestein, A History of Witchcraft, 139.

${ }^{21}$ Levack, "Possession and Witchcraft," 1615.

${ }^{22}$ Levack, "Possession and Witchcraft," 1630. 
it can reasonably be assumed that James had read The Discoverie of Witchcraft and that Scot's work had left him with information to ponder. The very fact that James eventually took it upon himself to uncover hoaxes offers confirmation of this suspicion.

Larner also questioned James' true motive in writing his book and pursuing witches. She questioned if his beliefs about witches were not because he truly believed in the power of witches and witchcraft and believed this power to be a direct threat to his life and kingdom, or whether his beliefs were formed out of anger at their presumed betrayal. ${ }^{23}$ Perhaps he had also questioned whether those who had expressed doubt in the reality of witchcraft were not in fact just as treasonous as the witches who would have killed him. Support for the notion that it was anger for treasonous acts such as threats to his life or to his kingdom being at the heart of his beliefs was demonstrated at least two times during his reign. The first incident was the result of a threat to his kingdom in 1605 in the form of prophecy that indicated, "there would be fire and sword throughout the land as a result of religious controversies". The accused, a man called Butler who had been described as a "poor creature," was dealt with harshly on the King behest, whipped and then sent before the Lord Chief Justice for further interrogation. The second incident occurred 1620 when James' life was again threatened with the use of witchcraft at the hands of a schoolmaster by the name of Peacock. James responded by having him locked in the Tower of London and interrogated under torture. ${ }^{24}$ These two incidents, when compared again the judicial norms over the period offer incite into the King's mindset and into English thinking. Although James had initiated the change in statute at the very onset of his reign in England, he had demonstrated restraint when it came to the witchcraft prosecutions, and only witchcraft based treason appeared to illicit a strong reaction from him. English law required royal permission to proceed to judicial torture; therefore, the majority of cases were heard by juries that pursued sound evidence. ${ }^{25}$ Evidence that Reginald Scot had advocated for in his effort to debunk witchcraft in 1584.

Reginald Scot was an influential skeptic and I believe that James I, at least privately, agreed with the truths that Scot had carefully laid out in The Discoverie of Witchcraft. While Scot's efforts did not bring about an immediate end to the witch trials, he did have an impact and had King James not scorned his work it is likely he could have been more influential in his lifetime. It is also reasonable to conclude that if an English country squire could see the fallacy of a belief in maleficent witchcraft caused by direct human interaction with demons, then so could the educated scholars and theologians. One can speculate that if James not been faced with a treasonous threat to his life and then convinced it had come at the hands of powerful

\footnotetext{
${ }^{23}$ Larner, Witchcraft and Religion, 13.

${ }^{24}$ Sharpe, Instruments of Darkness, 49.

${ }^{25}$ Gary K. Waite, Heresy, Magic, and Witchcraft in Early Modern Europe, (New York: Palgrave Macmillan, 2003), 117.
} 
Bercovice, "The Influence of Skepticism" 136

witches as his own book attested, he might have taken a different stance and supported Scot's efforts. 
Primary Sources:

\author{
Bibliography
}

Gibson, Marion, ed. Witchcraft and Society in England and America 1550-1750. New York: Cornell University Press, 2003.

James I, King of England, 1566-1625. Daemonologie. 1597. Project Gutenberg EBook accessed through Internet Archive.

Scot, Reginald. The Discoverie of Witchcraft. New York: Dover Publications, Inc., 1972

Secondary Sources:

Almond, Philip C. England's First Demonologist: Reginald Scot and 'The Discoverie of Witchcraft'. London: GBR: I.B. Tauris, 2011. ProQuest ebrary.

Davis, S. F. “The Reception of Reginald Scot's Discovery of Witchcraft: Witchcraft, Magic, and Radical Religion." Journal of the History of Ideas 74, no. 3 (2013):

381-401. Project Muse.

Larner, Christina. "Witches Beliefs \& Witch-hunting in England \& Scotland." History Today 31, no. 2 (1981): 32-36. EBSCOhost.

Larner, Christina. Witchcraft and Religion: The Politics of Popular Belief, edited by Alan Macfarlane. New York: Basil Blackwell, 1984.

Leland, L. Estes, and Scot, Reginald. "Reginald Scot and his 'Discoverie of Witchcraft': Religion and Science in the Opposition to the European Witch Craze." Church History 52, no. 4 (1983): 444-56. JSTOR.

Levack, Brian P. "Possession, Witchcraft, and the Law in Jacobean England." Washingtonand Lee Law Review 52, no. 5 (1995): 1613-40. http://scholarly commons.law.wlu.edu/wlulr/vol52/iss5/3

Notestein, Wallace. A History of Witchcraft in England from 1558 to 1718. Baltimore: The Lord Baltimore Press, 1911. Project Gutenberg EBook.

Sharpe, James. Instruments of Darkness: Witchcraft in Early Modern England. $\mathrm{P}$ h i ladelphia: University of Pennsylvania Press, 1996.

Teall, John L. "Witchcraft and Calvinism in Elizabethan England: Divine Power and Human Agency." Journal of the History of Ideas 23, no.1 (1962): 21-36. JSTOR.

Waite, Gary K. Heresy, Magic, and Witchcraft in Early Modern Europe. New York: Palgrave Macmillan, 2003. 
Bercovice, "The Influence of Skepticism" 138

Willis, Deborah. Malevolent Nurture: Witch-Hunting and Maternal Power in Early Modern England. London: Cornell University Press, 1995. 